\title{
Additive Manufacturing in Land Vehicle Industry
}

\author{
Ersoy $\mathrm{K}^{1 *}$, Yasa $\mathrm{E}^{2}$ and Koç $\mathrm{B}^{1}$ \\ ${ }^{1}$ FNSS Defence Industries, Ankara, Turkey \\ ${ }^{2}$ Department of Mechanical Engineering, Osmangazi University, Eskisehir, Turkey
}

*Corresponding author: Kıvılcım Ersoy, FNSS Defence Industries, Ankara, Turkey.

To Cite This Article: Ersoy K, Additive Manufacturing in Land Vehicle Industry. Am J Biomed Sci \& Res. 2019 - 6(5). AJBSR.MS.ID.001079.

DOI: 10.34297/AJBSR.2019.06.001079.

Received: 䟧 December 03, 2019; Published: 海 December 20, 2019

\begin{abstract}
Additive manufacturing has been gaining more importance in the recent years for diverse applications due to its various advantages like mass customization, enabling very complex geometries, weight reduction, lead time and cost advantage for small volume production. Additive manufacturing has become an almost mature technology group in biomedical applications for different materials. However, aerospace and defense industries are still investigating its feasibility for a wide range of applications due to strict and demanding requirements. The land vehicle industry demands mainly small series and cost efficient production of parts to be used in arduous conditions in battlefield. Even more importantly, the short lead time and the possibility to produce at the battle field makes the additive technologies significant for the land vehicle industry. This paper will focus on the road mapping and prioritization of additive technologies for land vehicles taking the boundary conditions and requirements of the land vehicle industry into account and will depict some of the results of the action items driven from additive technology roadmap.
\end{abstract}

Keywords: Additive manufacturing; Road mapping; Land vehicles; Defense applications

\section{Introduction}

Additive Manufacturing (AM) technologies are emerging very fast in the recent decade and is regarded as a complementary technology to Industry 4.0. Evidently, there are many AMprocesses and it is important to identify and prioritize these methods and materials appropriate for a sector and company in terms of application requirements. This process may be referred to as roadmapping to maximize the benefit and potential of AM for a specific company. In fact, this has been done several times for countries [1,2] or regions [2-4] in the world. Although these roadmaps specifies the importance of AM technologies for diverse industries and demonstrate some examples, they do not assist in developing a methodology to select the most suitable parts and processes for a specific sector. Additionally, there are some brief information or qualitative guidelines on how to select the right AM technology for a specified business [5, 6]. Yet, these resources only provide a general outline but most of the time, they stay insufficient to determine in which way to $g$ oto maximize the benefit and to comfirm the feasibility of AM technologies for a specified company manufacturing a diverse portfolio of demanding products. Thus, this paper aims at presenting a methodology to roadmap AM technologies for land vehicle applications. Yet, the methodology can be extended to various application areas taking the various constraints into account. Therefore, the boundary conditions for land vehicle industry are first explained followed by the procedure. Moreover, some examples of the applied roadmapping methodology are presented.

\section{Typical Trends and Corresponding Requirements of Land Vehicle Industry}

As the defence industry explores new materials and manufacturing processes to be more and more innovative at a reduced cost and improved performance, Additive Manufacturing, as an enabling technology, is of great importance. AM technologies are not only disruptive in terms of manufacturing constraints, but they are also changing the whole value chain starting from design to manufacturing including aftersale services as they are capable of producing customized parts on demand and in or near to the place of use. In the last decade, manufacturers, defence organisations and military end-users have continually been assessing how these technologies can be used to reduce costs, increase the pace of development, and strengthen supply chain resilience [7]. Even 
different applications in defence industries may call for different constraints.

For example, for an Unmanned Air Vehicle (UAV), weight reduction will be of great interest whereas for a land vehicle, shorter lead times may be a more critical factor while reduced weight at an improved performance will be a plus. The recent trends of land vehicle industry, thus constraints, can be summarized as follows:

\section{Availability and value chain}

In order to be able to fight-capable on field all the time, short lead times are indispensable. Here, value is not to be regarded only as money, but also as time and readiness as well as preparedness to operate at any time.

\section{Typical materials and part size}

Even if there are parts of various size, land vehicles typically work with larger size parts. Due to cost efficiency requirements and the arduous loading conditions on the battlefield, typically conventional metallic materials are commonly used.

\section{Cost}

In the recent years, many countries have localization initiates and there are numerous new land vehicle producers. With the new incomers to land vehicle industry, the pieces get very competitive and cost efficiency gets more and more important.

\section{Lightweight design}

In the recent years, the enhancements in destructive technologies necessitate higher requirements for survivability; both for mine, ballistic and Intelligent Electronic Device (IED) protection. At the same time, payloads increase and mobility requirements are becoming more challenging. These trends make lightweight design indispensable.

\section{Technology drives military}

Military and other industrial technological developments always go hand-in-hand. In some decades, the military drove the technology, but in 2000s the technology leads the military applications, like Industry 4.0, internet of things, artificial intelligence, additive manufacturing, etc. Using and implementing today's technology into military applications is crucial. In current times, technology evolves faster than the people and organizations. So, it is important to follow the evolving technologies, to identify the most promising ones matching with the requirements of land vehicle industry and to innovate the procedures, processes and people as well as parts and the products.

\section{Roadmapping of Additive Manufacturing for Land Vehicle Industry}

\section{Methodology}

The technology roadmap is a structured flexible planning to support the integrated business plan and communicates the technology goals and initiatives to the company. The additive manufacturing roadmap consists of mainly five focus areas with integrated objectives. These focus areas are need identification, design, material, process, value chain as shown in shown in Figure 1. The path to form and execute the roadmap is depicted in Figure 2. As demonstrated, first of all, the focus areas need to be identified followed by articulating the goals and prepareing action plans. Finally, it should be checked whether the outcomes serve for the objective goals or not. The main objective is to make best use of the advantages of additive technologies for defense industry taking the typical trends and requirements. As additive manufacturing technologies are emerging and evolving technologies, it is important to update the roadmap and the action planning according to the main objective as often as needed.

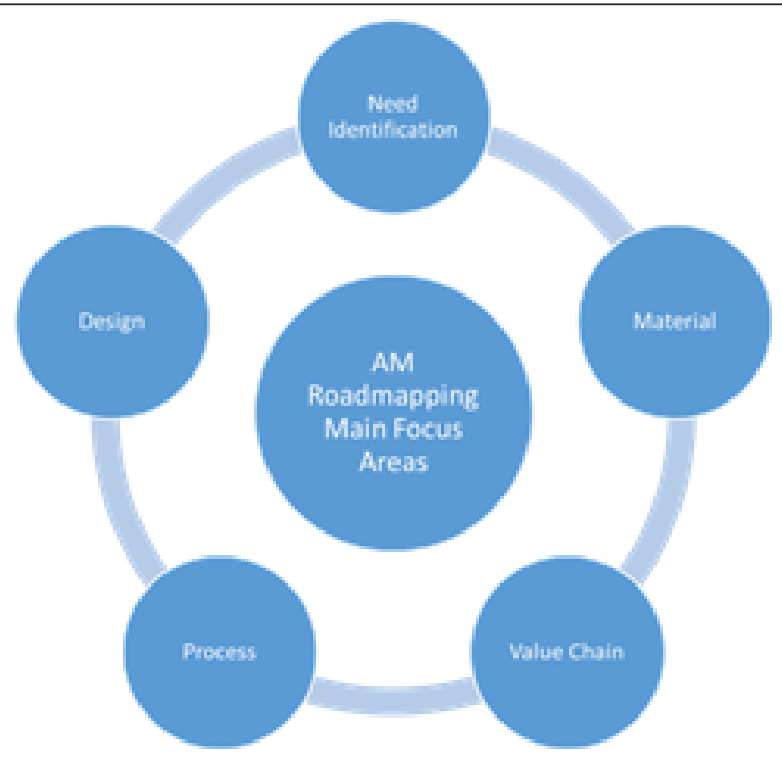

Figure 1: The focus areas of the AM roadmap. 


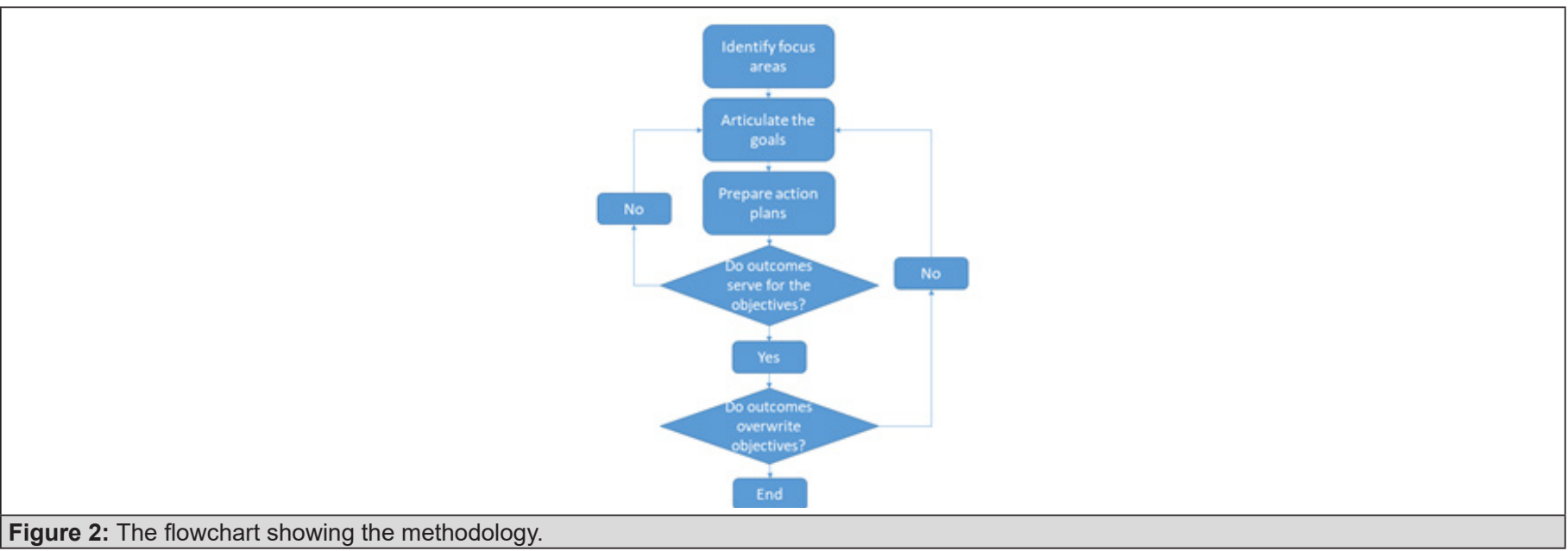

\section{Need identification}

For each application, there are different needs according to the functional and environmental requirements. So, each component's requirements are to be evaluated case by case by taking the real needs of the end-user from this component into account. All requirements need to be identified in order to enable additive design and afterwards the appropriate material and process is to be selected. Some examples of the needs can be related to the surface quality, dimensional accuracy, mechanical properties and defects.

\section{Design}

Design work package aims to introduce a new design methodology to change the conventional design rules based on traditional manufacturing techniques. The new design methodology has to serve to utilize the advantage of additive processes taking the design for additive manufacturing. Although the geometrical complexity enabled by AM is almost unlimited, there are rules related to the overhang structures, minimum feature sizes, part integration, etc. Each AM process imposes different design constraints. Depending on the application, the process shall be chosen by taking not only the requirements, material and part size but also design considerations into account.

\section{Material}

Nowadays, there are various metallic and non-metallic materials, which can be used in additive technologies. This work package focuses on identification of the most appropriate materials for the land vehicle industry. For a mid-level industrial company, it is not about to develop a new material but to follow the developments in technology in additive manufacturing materials and evaluate their performance within the additive processes.

\section{Process}

As evident, there are many AM-processes working with different materials $[8,9]$. The selection of the most suitable process for a specific application needs experienced staff and good knowledge of available processes as well as the of the requirements of the specific application. In order to facilitate the process selection, a structured methodology is established. For a specific part, the appropriate process should be chosen taking the following parameters into account: maximum part size, available materials, mechanical properties, build speed, building accuracy, surface quality, investment cost and production cost.

There are two kind of factors that should be considered as a rating mechanism to choose appropriate process. To give a rough down-selection, the value of these factors for a piece part needs to be identified. The first factor that should be established is part factor. This factor is independent from the process, but it highly depends on the component's function and related requirements. For instance, for a structurally load carrying large part, the build size capacity is of crucial importance (part factor: 9), material properties are of high importance (part factor: 7), surface quality is almost negligible (part factor: 1) and cost is of reasonable importance (part factor: 5).

Following that, the same parameters are to be evaluated for the available process, which gives the second variable, process factor, which is directly related to the AM-process itself. The assessment for process factor is accomplished with the best knowledge of state-of-the-art. For instance, process factors for Wire Arc Additive Manufacturing (WAAM) can be written as: 9 for part size (very large parts can be accommodated), 5 for material properties (good mechanical properties but may need post-processes), 1 for surface quality (almost always needs machining) and 9 for production cost (low operational and investment cost). On the other hand, the same factors can be evaluated for SLM process like following: 1 for part size (due to limitations on the part size), 5 for material properties (good mechanical properties but may need post-processes), 9 for surface quality (in comparison to other AM technologies) and 1 for cost (still an expensive methodology)

Then these two factors corresponding to the same property (ie. part factor of surface quality and process factor of surface quality) need to be multiplied. This operation had to be done seperately for each property. Finally, all values should be summed up and compared each other to find the best method. Although this easy 
technique gives a rough estimation for finding the most appropriate process, the selection of processes is generally quite a complicated task, since there are lots of processes suitable for metallic and composite Materials, which are of interest. It should be also noted that assignment of numeric values to the qualitative assessments of the process factors is accomplished on the basis of FNSS' bestpractices and open literature knowledge [10]. Thus, it can be said that even with this methodology, the expertise in AM technologies is a prerequisite. Moreover, it is important to note that this method is to be used for the first down-selection.

Table $1 \& 2$ depict the process evaluation factors for polymerbased and metallic materials respectively with the best known data from state-of-the-art literature [9,11-13]. As expected, with the advancement of the technologies these tables are also subject to change.

\begin{tabular}{|c|c|c|c|c|c|c|c|c|c|c|c|c|c|}
\hline \# & $\begin{array}{l}\text { Process } \\
\text { Catego- } \\
\text { ry }\end{array}$ & $\begin{array}{l}\text { Ma- } \\
\text { terial } \\
\text { group }\end{array}$ & $\begin{array}{l}\text { Available } \\
\text { materials }\end{array}$ & Process & $\begin{array}{c}\text { State } \\
\text { of the } \\
\text { starting } \\
\text { material }\end{array}$ & $\begin{array}{l}\text { Typical } \\
\text { applica- } \\
\text { tions }\end{array}$ & $\begin{array}{l}\text { Build } \\
\text { speed }\end{array}$ & $\begin{array}{l}\text { Accu- } \\
\text { racy }\end{array}$ & $\begin{array}{c}\text { Sur- } \\
\text { face } \\
\text { qual- } \\
\text { ity }\end{array}$ & $\begin{array}{l}\text { Max. } \\
\text { part } \\
\text { size }\end{array}$ & $\begin{array}{c}\text { Invest- } \\
\text { ment } \\
\text { cost }\end{array}$ & $\begin{array}{c}\text { Pro- } \\
\text { duction } \\
\text { cost }\end{array}$ & $\begin{array}{c}\text { Me- } \\
\text { chanical } \\
\text { proper- } \\
\text { ties }\end{array}$ \\
\hline 1 & $\begin{array}{c}\text { Material } \\
\text { Extru- } \\
\text { sion }\end{array}$ & $\begin{array}{l}\text { Poly- } \\
\text { mers }\end{array}$ & $\begin{array}{l}\text { ABS, PPS, } \\
\text { PEKK, } \\
\text { PEI, ASA, } \\
\text { PC, PPSF, } \\
\text { PA and } \\
\text { ULTEM }\end{array}$ & $\begin{array}{l}\text { Fused } \\
\text { Filament } \\
\text { Fabrica- } \\
\text { tion }\end{array}$ & Filament & $\begin{array}{l}\text { Functional } \\
\text { Proto- } \\
\text { type/ Part } \\
\text { Manufac- } \\
\text { turing }\end{array}$ & ++ & + & + & + & $\$$ & $\$$ & + \\
\hline 2 & $\begin{array}{c}\text { Material } \\
\text { Extru- } \\
\text { sion }\end{array}$ & $\begin{array}{l}\text { Poly- } \\
\text { mers }\end{array}$ & $\begin{array}{l}\text { ABS, PPS, } \\
\text { PEKK and } \\
\text { ULTEM }\end{array}$ & $\begin{array}{l}\text { Big Area } \\
\text { AM } \\
\text { (BAAM) }\end{array}$ & Filament & $\begin{array}{l}\text { Functional } \\
\text { Proto- } \\
\text { type/ Part } \\
\text { Manufac- } \\
\text { turing }\end{array}$ & +++ & + & + & +++ & $\$ \$ \$$ & $\$ \$$ & + \\
\hline 3 & $\begin{array}{l}\text { Powder } \\
\text { Bed } \\
\text { Fusion }\end{array}$ & $\begin{array}{l}\text { Poly- } \\
\text { mers }\end{array}$ & $\begin{array}{l}\text { Polyamide, } \\
\text { PEEK, } \\
\text { Polysty- } \\
\text { rene }\end{array}$ & $\begin{array}{l}\text { Selective } \\
\text { Laser } \\
\text { Sintering }\end{array}$ & Powder & $\begin{array}{l}\text { Functional } \\
\text { Proto- } \\
\text { type/ Part } \\
\text { Manufac- } \\
\text { turing }\end{array}$ & + & ++ & ++ & + & $\$ \$ \$$ & $\$ \$$ & ++ \\
\hline 4 & $\begin{array}{l}\text { Sheet } \\
\text { Lamina- } \\
\text { tion }\end{array}$ & $\begin{array}{l}\text { Poly- } \\
\text { mers }\end{array}$ & $\begin{array}{l}\text { PEEK, PEI, } \\
\text { PPS, PP, } \\
\text { PE, PC, } \\
\text { PET, PES, } \\
\text { Nylon, } \\
\text { PEKK }\end{array}$ & $\begin{array}{c}\text { Selective } \\
\text { Lami- } \\
\text { nation } \\
\text { Compos- } \\
\text { ite Object } \\
\text { Manufac- } \\
\text { turing }\end{array}$ & Sheet & $\begin{array}{c}\text { Functional } \\
\text { Prototype } \\
\text { / Part } \\
\text { Manufac- } \\
\text { turing }\end{array}$ & & & ++ & ++ & $\$ \$ \$$ & $\$$ & \\
\hline 5 & $\begin{array}{c}\text { Material } \\
\text { Extru- } \\
\text { sion }\end{array}$ & $\begin{array}{l}\text { Com- } \\
\text { posites }\end{array}$ & $\begin{array}{l}\text { Carbon fi- } \\
\text { ber, Kevlar } \\
\text { fiber, or } \\
\text { glass fiber } \\
\text { reinforced } \\
\text { thermo- } \\
\text { plastics }\end{array}$ & $\begin{array}{l}\text { Fused } \\
\text { Filament } \\
\text { Fabrica- } \\
\text { tion }\end{array}$ & Filament & $\begin{array}{c}\text { Functional } \\
\text { Prototype } \\
\text { / Part } \\
\text { Manufac- } \\
\text { turing }\end{array}$ & ++ & + & + & + & $\$$ & $\$$ & + \\
\hline 6 & $\begin{array}{c}\text { Material } \\
\text { Extru- } \\
\text { sion }\end{array}$ & $\begin{array}{l}\text { Com- } \\
\text { posites }\end{array}$ & $\begin{array}{l}\text { Carbon } \\
\text { fiber or } \\
\text { glass fiber } \\
\text { reinforced } \\
\text { thermo- } \\
\text { plastics } \\
\end{array}$ & $\begin{array}{l}\text { Big Area } \\
\text { AM } \\
\text { (BAAM) }\end{array}$ & Filament & $\begin{array}{l}\text { Functional } \\
\text { Proto- } \\
\text { type/ Part } \\
\text { Manufac- } \\
\text { turing }\end{array}$ & +++ & + & + & +++ & $\$ \$ \$$ & $\$ \$$ & + \\
\hline 7 & $\begin{array}{l}\text { Powder } \\
\text { Bed } \\
\text { Fusion }\end{array}$ & $\begin{array}{l}\text { Com- } \\
\text { posites }\end{array}$ & $\begin{array}{l}\text { Alumide } \\
\text { (polyam- } \\
\text { ide Al- } \\
\text { filled), Car- } \\
\text { bonmide } \\
\text { (Polyam- } \\
\text { ide carbon } \\
\text { rein- } \\
\text { forced) }\end{array}$ & $\begin{array}{l}\text { Selective } \\
\text { Laser } \\
\text { Sintering }\end{array}$ & Powder & $\begin{array}{l}\text { Functional } \\
\text { Proto- } \\
\text { type/ Part } \\
\text { Manufac- } \\
\text { turing }\end{array}$ & + & ++ & ++ & + & $\$ \$ \$$ & $\$ \$$ & ++ \\
\hline
\end{tabular}




\begin{tabular}{|c|c|c|c|c|c|c|c|c|c|c|c|c|c|}
\hline 8 & $\begin{array}{l}\text { Sheet } \\
\text { Lamina- } \\
\text { tion }\end{array}$ & $\begin{array}{l}\text { Com- } \\
\text { posites }\end{array}$ & $\begin{array}{l}\text { Carbon } \\
\text { fiber, } \\
\text { fiberglass, } \\
\text { aramid } \\
\text { fiber and } \\
\text { metal } \\
\text { fibers } \\
\text { reinforced } \\
\text { thermo- } \\
\text { plastics }\end{array}$ & $\begin{array}{l}\text { Selective } \\
\text { Lami- } \\
\text { nation } \\
\text { Compos- } \\
\text { ite Object } \\
\text { Manufac- } \\
\text { turing }\end{array}$ & Sheet & $\begin{array}{c}\text { Functional } \\
\text { Prototype } \\
\text { / Part } \\
\text { Manufac- } \\
\text { turing }\end{array}$ & ++ & ++ & ++ & ++ & $\$ \$ \$$ & $\$ \$ \$$ & ++ \\
\hline 9 & $\begin{array}{c}\text { Sheet } \\
\text { Lamina- } \\
\text { tion }\end{array}$ & $\begin{array}{l}\text { Com- } \\
\text { posites }\end{array}$ & $\begin{array}{l}\text { Thermo- } \\
\text { plastics } \\
\text { reinforced } \\
\text { with } \\
\text { anything } \\
\text { from car- } \\
\text { bon fiber, } \\
\text { fiberglass, } \\
\text { polyester, } \\
\text { polyvinyl } \\
\text { alcohol } \\
\text { and PLA } \\
\text { to silk and } \\
\text { cotton }\end{array}$ & $\begin{array}{l}\text { CBAM } \\
\text { (Compos- } \\
\text { ite based } \\
\text { AM) }\end{array}$ & Sheet & $\begin{array}{c}\text { Functional } \\
\text { Prototype } \\
\text { /Part } \\
\text { Manufac- } \\
\text { turing }\end{array}$ & & + & + & + & $\$ \$$ & $\$ \$$ & +++ \\
\hline
\end{tabular}

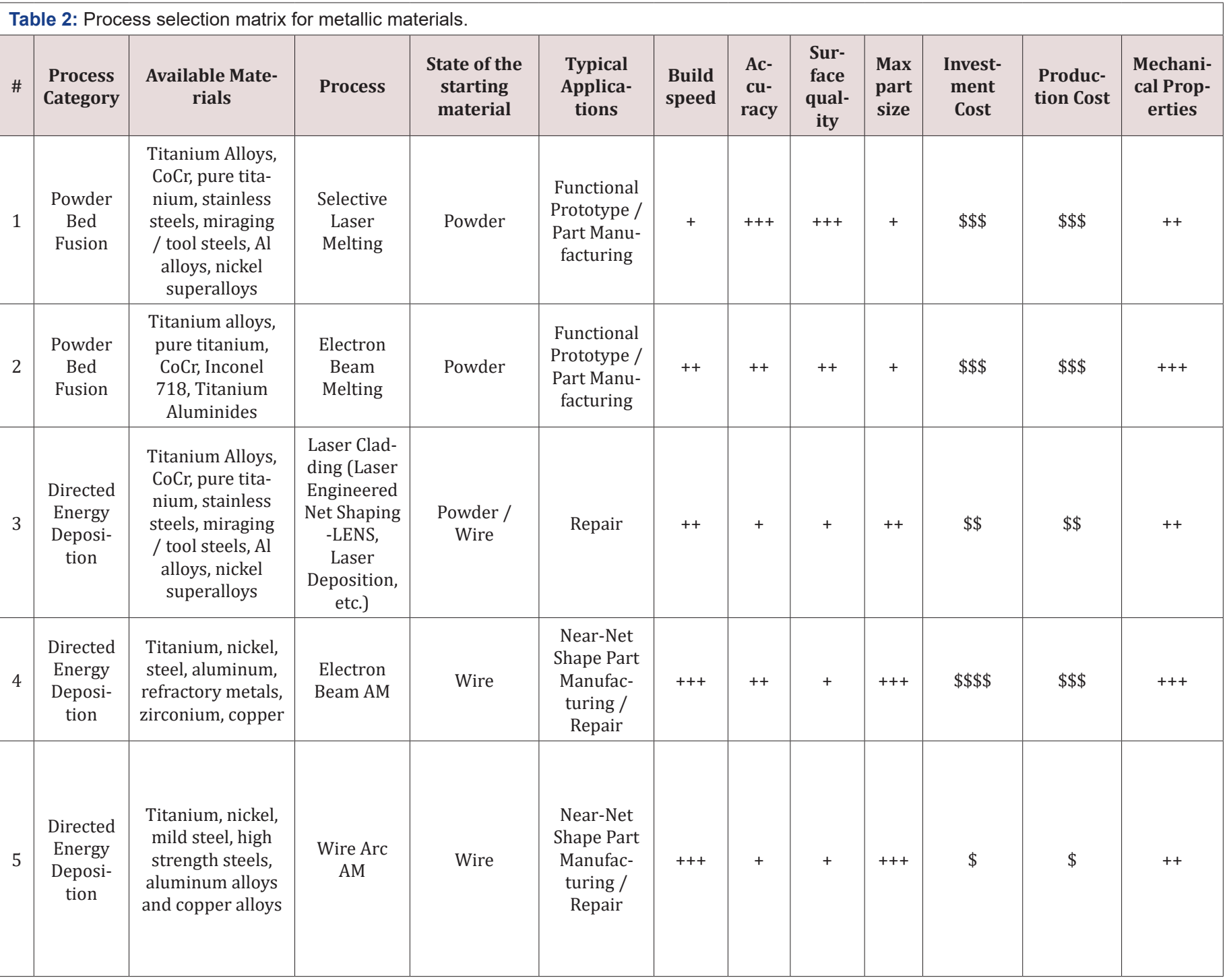




\begin{tabular}{|c|c|c|c|c|c|c|c|c|c|c|c|c|}
\hline 6 & $\begin{array}{l}\text { Directed } \\
\text { Energy } \\
\text { Deposi- } \\
\text { tion }\end{array}$ & $\begin{array}{c}\text { Titanium alloys, } \\
\text { nickel superalloys, } \\
\text { steels }\end{array}$ & $\begin{array}{l}\text { Shaped } \\
\text { Metal } \\
\text { Deposition }\end{array}$ & Powder & $\begin{array}{l}\text { Near-Net } \\
\text { Shape Part } \\
\text { Manufac- } \\
\text { turing / } \\
\text { Repair }\end{array}$ & +++ & + & + & +++ & $\$ \$$ & $\$ \$$ & ++ \\
\hline 7 & $\begin{array}{l}\text { Sheet } \\
\text { Lamina- } \\
\text { tion }\end{array}$ & $\begin{array}{c}\text { Aluminum, } \\
\text { copper, steel, tita- } \\
\text { nium, nickel, gold, } \\
\text { silver, refractory } \\
\text { metal }\end{array}$ & $\begin{array}{l}\text { Ultrasonic } \\
\text { Additive } \\
\text { Manu- } \\
\text { facturing } \\
\text { (Ultrasonic } \\
\text { Freeform } \\
\text { Consolida- } \\
\text { tion) }\end{array}$ & Metal Foils & $\begin{array}{l}\text { Near-Net } \\
\text { Shape Part } \\
\text { Manufac- } \\
\text { turing }\end{array}$ & ++ & + & + & +++ & $\begin{array}{l}\$ \$ \$ \text { (sold } \\
\text { in hybrid } \\
\text { form) }\end{array}$ & $\begin{array}{l}\text { \$\$ (sold } \\
\text { in hybrid } \\
\text { form) }\end{array}$ & ++ \\
\hline 8 & $\begin{array}{l}\text { Material } \\
\text { Extru- } \\
\text { sion }\end{array}$ & $\begin{array}{l}\text { Stainless Steels, } \\
\text { Aluminum, Titani- } \\
\text { um, nickel super- } \\
\text { alloys, Carbides, } \\
\text { high performance } \\
\text { steels, tungsten } \\
\text { alloy, Copper, } \\
\text { Bronze, low } \\
\text { expansion Invar / } \\
\text { Kovar }\end{array}$ & $\begin{array}{l}\text { Fused } \\
\text { Deposition } \\
\text { Modeling }\end{array}$ & Filament & $\begin{array}{c}\text { Functional } \\
\text { Prototype/ } \\
\text { Part Manu- } \\
\text { facturing }\end{array}$ & ++ & + & + & + & $\$ \$$ & $\$$ & + \\
\hline 9 & $\begin{array}{l}\text { Binder } \\
\text { Jetting }\end{array}$ & $\begin{array}{c}420 \text { Stainless } \\
\text { Steel / Bronze } \\
\text { Matrix, 316 Stain- } \\
\text { less Steel / Bronze } \\
\text { Matrix, 316L } \\
\text { Stainless Steel, } \\
\text { 17-4PH Stainless } \\
\text { Steel, IN Alloy } \\
\text { 625, IN Alloy 718, } \\
\text { Iron / Bronze } \\
\text { Matrix, WC, } \\
\text { Iron-Chrome-Alu- } \\
\text { minum }\end{array}$ & $\begin{array}{l}\text { Binder Jet- } \\
\text { ting Binder }\end{array}$ & $\begin{array}{c}\text { Powder + } \\
\text { Material }\end{array}$ & $\begin{array}{c}\text { Proto- } \\
\text { typing / } \\
\text { non-struc- } \\
\text { tural parts }\end{array}$ & ++ & ++ & ++ & +++ & $\$ \$$ & $\$ \$$ & + \\
\hline
\end{tabular}

\section{Value chain}

Availability, i.e. being capable of defence all the time and in various places, is indispensable for land vehicle industry. Especially, for mission critical equipment, it is eminent to be supplied in battlefield in very short times. Additive technologies enable decentral- ized and on-demand manufacturing, which enables support the value chain at battle field. This simplified supply chain enables not only short supply time and low inventory turnover, it also allows space for quick design changes and design customization. Regarding each focus area, goals and actions are identified driven by the AM roadmap for land vehicles as shown in Table 3.

Table 3: Regarding each focus area, goals and actions identified driven by the AM roadmap for land vehicles.

\begin{tabular}{|c|c|}
\hline \multirow{2}{*}{$\begin{array}{l}\text { A. Need identifi- } \\
\text { cation }\end{array}$} & Identify the needs for components correctly and differentiate between the requirements. \\
\hline & $\begin{array}{l}\text { Apply design thinking strategies to identify the real needs of a subsystem or component to facilitate to let go of conventional design } \\
\text { mentality. }\end{array}$ \\
\hline \multirow[t]{2}{*}{ B. Design } & $\begin{array}{l}\text { Populate design for AM and all design strategies to support AM-design (generative design, topology optimization, multi-physics } \\
\text { optimization) and modify the conventional design processes if necessary. }\end{array}$ \\
\hline & Educate engineers and designers about AM-design \\
\hline \multirow{3}{*}{ C. Material } & Define the materials, which can be utilized for land vehicle parts meeting the requirements. \\
\hline & Investigate the mechanical properties of the materials combined with the appropriate production process. \\
\hline & Develop supply chain for these selected materials \\
\hline \multirow{3}{*}{ D. Process } & Follow the promising AM processes under development. \\
\hline & Identify the most robust AM processes meeting the requirements of land vehicles. \\
\hline & Evaluate possible in- and outsource strategies \\
\hline \multirow{4}{*}{ E. Value Chain } & Create value matrix to identify the parts to be design and manufactured with additive manufacturing. \\
\hline & Establish cost-value models and decision tools. \\
\hline & Prepare business practices and infrastructure. \\
\hline & Create best practices for make-buy as well as investment decisions \\
\hline
\end{tabular}




\section{Results from AM Road Map Goals}

The results to be presented here belong the studies within the acion items of material and process from Table 3 . The results are given for polymer based and metallic based Materials in two sections trying to address the following action items:

A. Define the materials, which can be utilized for land vehicle parts meeting the requirements,

\section{Polymer based parts and materials}

(a)

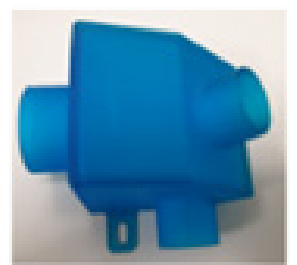

(b)

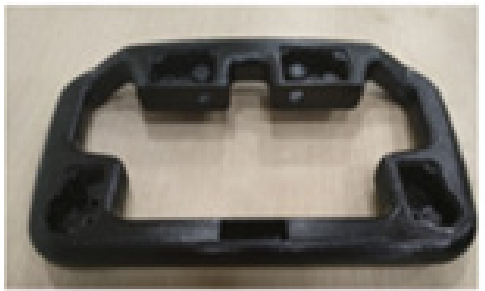

(c)

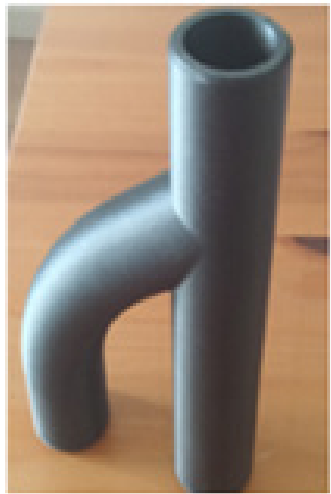

Figure 3: a) Non-load carrying cover made out of polymer-based material b) Prototype industrial design made out of polymer based material by fused filament fabrication c) Tube geometry made out of chopped carbon fiber reinforced polymer material produced by fused filament fabrication (original part aluminum).

Plastic parts can be used for prototyping as well as nonload carrying cover parts, whereas reinforced polymer-matrix composite parts need to be evaluated for their potential to replace metallic load carrying parts leading to weight reduction. Plastic 3D printed parts for prototyping is of best practice now for many industries as it offers a quick tangible answer to industrial design questions. Examples can be seen in Figure 3a-3c. Regarding the polymer-matrix composites, a feasibility study was conducted
B. Investigate the mechanical properties of the materials combined with the appropriate production process,

C. Follow the promising AM processes under development,

D. Identify the most robust $\mathrm{AM}$ processes meeting the requirements of land vehicles.

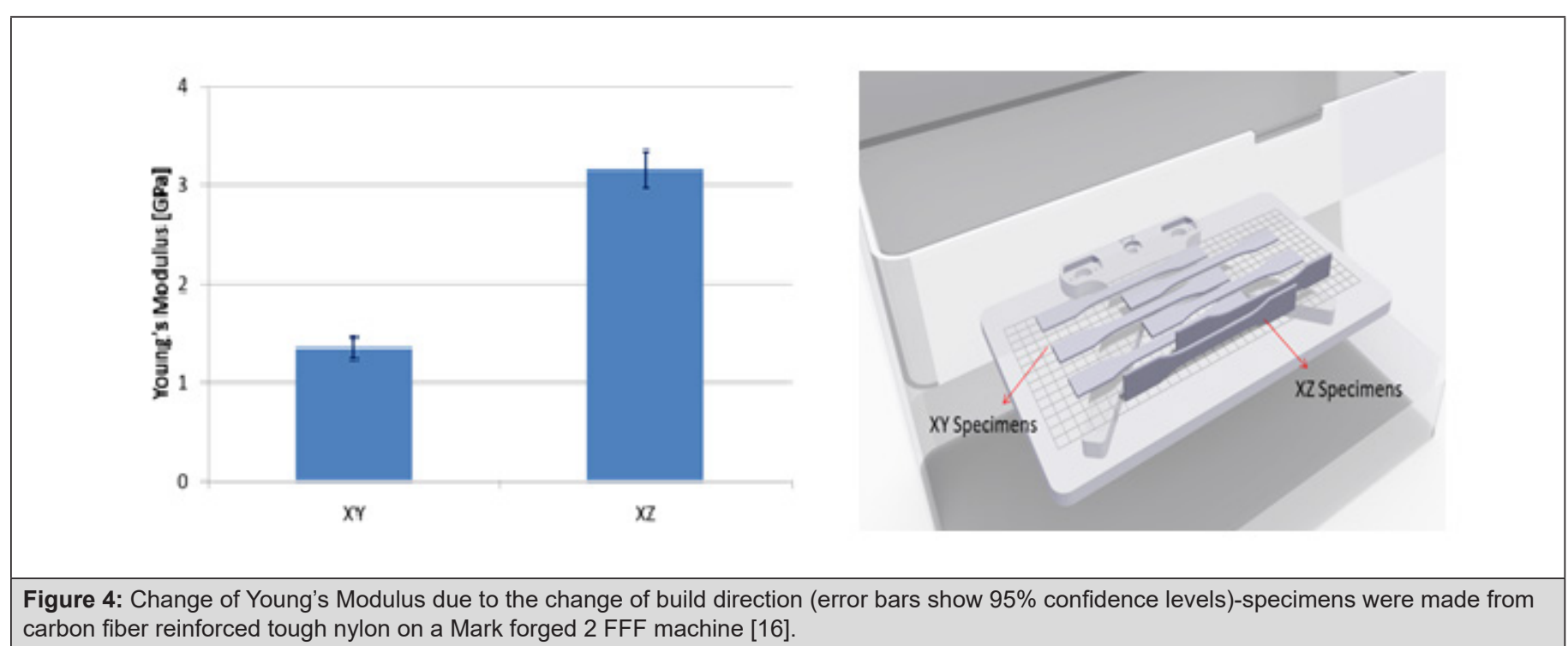

to identify whether the carbon fiber reinforced polymers could replace aluminum alloys. A demo part is shown in Figure 3c where leakage tests were performed on. Without any post-processing, the built specimens could not succeed the leakage tests due to lack of adequate fusion mechanisms in between successive layers. The mechanical properties of the chopped carbon fiber reinforced nylon were also investigated.

carbon fiber reinforced tough nylon on a Mark forged 2 FFF machine [16]. 
The results show that the anisotropy encountered in mechanical properties is a significant barrier for utilizing this material and process combination in structural parts, because there is a lack of good bonding between successive layers $[14,15]$. The elasticity modulus of specimens built in different directions significantly differs as shown in Figure 4. All process variables are the same for two tests, except for the build direction. Results show that anisotropy encountered in chopped carbon fiber reinforced nylon specimens are crucial because this non-uniformity prevents the component to resist stresses at the same level in all directions. This result indicates that chopped carbon fiber reinforced nylon components are not very suitable for structural parts sensitive orientation-dependent loading.

\section{Metallic parts and materials}

(a)

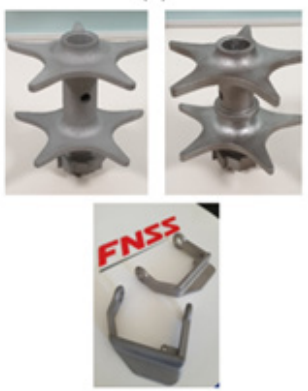

(b)

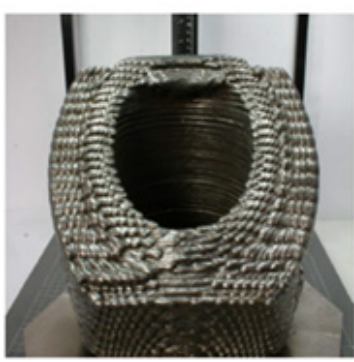

Figure 5: a) Structural parts produced by SLM and binder jetting b) Structural part produced by WAAM.

The priorities of land vehicles for one group of metallic parts can be summarized as high accuracy, high surface quality, high geometrical complexity, low operational/investment cost with good mechanical properties. On the other hand, for another group of parts, maximum build volume to allow large part manufacturing, high build rates, low operational/investment cost with good mechanical properties are more critical. For this second group, surface quality and accuracy can be compensated with secondary operations. Examples from both groups can be seen in Figure 5. For the first group of materials, SLM and binder jetting methodologies for the stainless steel material have been investigated, whereas WAAM is an advantageous method to produce large parts in terms of cost and part size.

However, WAAM is not a net shape manufacturing technology. The end geometry and surface quality of WAAM products need to be revised by complementary subtractive manufacturing technologies. A study is conducted to evaluate whether binder jetting and SLM produced metallic parts could be an alternative for conventionally manufactured parts. The components chosen are produced conventionally with casting technologies. Parts produced with binder jetting method were out of geometric tolerance, whereas SLM gives acceptable end geometry conforming to the tolerances. Thus, the dependece of the mechanical properties of the SLM parts on the build direction were investigated. In the study, specimens produced along different build directions are exposed to tensile stresses.

According to the build orientation, different values of Yield Strength (YS), Ultimate Tensile Strength (UTS) and Young's Modulus have been obtained as shown in Table 4. Results showed that changes in yield strength, ultimate tensile strength and Young's modulus complies with the standards and there is not a remarkable anisotropy in different build directions. According to this data, with preliminary study metallic parts produced with SLM technologies may be an option to conventionally casted parts which are limited in size. The end decision must be given taking the geometry, cost and supply chain constraints into account [16].

Table 4: Yield Strength, Ultimate Tensile Strength and Young's Modulus for same specimen, different directions for specimen of $3 \mathrm{~mm}$ thickness.

\begin{tabular}{|c|c|c|c|c|}
\hline$\#$ & Orientation & Yield Strength [MPa] & Ultimate Tensile Strength [MPa] & Young's Modulus [GPa] \\
\hline 1 & $0-90-0^{\circ}$ & $416 \pm 22$ & $648 \pm 5$ & $20 \pm 0.7$ \\
\hline 2 & $0-0-0^{\circ}$ & $378 \pm 14$ & $574 \pm 4$ & $19 \pm 1.1$ \\
\hline 3 & $0-90-90^{\circ}$ & $403 \pm 5$ & $649 \pm 6$ & $21 \pm 0.4$ \\
\hline
\end{tabular}

\section{Conclusions}

Evidently additive technologies are in a phase of development and have many successful applications in different industries. In this paper a methodology to identify the significant additive technologies for land vehicle industry is offered and illustrated with specific examples. It is important to note that decisions on specific parts must be given in each case taking the requirements, constraints, technical and functional limitations, cost and supply conditions into account. 


\section{References}

1. Du-Preez WB, De-Beer DJ (2014) Implementing the South African AM technology roadmap-the role of AM Centre of Competence. South Africa.

2. Scott C (2017) China introduces new action plan for advancement of 3D printing industry.

3. Johnston T, Smith TD, Irwin JL (2018) Additive Manufacturing in 2040. RAND Corporation 31

4. Deliverable of AM-Motion Project (Grant Agreement № 723560).

5. Voets L (2018) Additive Manufacturing Technologies: How to make the right choice (e-book).

6. Reiher T, Lindemann C, Jahnke U, Deppe G, Koch R (2017) Holistic approach for industrializing AM technology: from part selection to test and verification. Prog Addit Manuf 2: 43-55.

7. Turnbull G (2019) 3D Printing: Where next for additive manufacturing in defence. Global Defence Technology.

8. Fielding J, Gorham R, Davis A, Bouffard B, Morris K (2016) Department of Defense, Additive Manufacturing RoadMap.

9. Wohlers T (2017) Wohlers Report

10. Ersoy K, Koc B, Yasa E (2018) A Technological and Business Perspective of Additive Manufacturing for Defense Industry, The 18th International Conference on Machine Design and Production UMTIK Conference Proceedings.
11. Ersoy K, Yasa E (2018) A Review on the Additive Manufacturing of Fiber Reinforced Polymer Matrix Composites. SFF (Solid Freeform Fabrication) Symposium-An Additive Manufacturing Conference, Austin.

12. Yakout M, Elbestawi MA, Veldhuis SC (2018) A Review of Metal Additive Manufacturing Technologies. Solid State Phenomena 278: 1-14.

13. Serin G, Kahya M, Ünver HÖ, Güleç Y, Durlu N, et al. (2016) A review of AM technologies, The 17th International Conference on Machine Design and Production. Bursa, Turkey.

14. Yasa E, Ersoy K (2019) Dimensional Accuracy and Mechanical Properties of Chopped Carbon Reinforced Polymers Produced by Material Extrusion Additive Manufacturing. Materials 12(23): 3885

15. Yasa E (2019) Anisotropic impact toughness of chopped carbon fiber reinforced nylon fabricated by material extrusion based additive manufacturing. A Appl Sci Eng 20(2): 195-203.

16. Yasa E, Ersoy K, Koc B (2019) On The Effect of Unfixed Process Variables on Mechanical Properties in Selective Laser Melting. AMC Conference Preceedings, İstanbul, Turkey. 